\title{
Circulating hyaluronate in rheumatoid arthritis: relationship to inflammatory activity and the effect of corticosteroid therapy
}

\author{
ANNA ENGSTRÖM-LAURENT AND ROGER HÄLLGREN \\ From the Institute of Medical and Physiological Chemistry, the Biomedical Centre, and the Department of \\ Internal Medicine, University Hospital, Uppsala, Sweden
}

SUMMARY The mean serum hyaluronate concentration in a group of patients with rheumatoid arthritis $(\mathrm{n}=37)$ was $232 \pm 182(\mathrm{SD}) \mu \mathrm{g} / \mathrm{l}$ and significantly greater $(\mathrm{p}<0.001)$ than that of age and sex matched healthy controls (mean level $42 \pm 25 \mu \mathrm{g} / \mathrm{l}$ ) as well as that of patients with ankylosing spondylitis (mean level $58 \pm 33 \mu \mathrm{g} / \mathrm{l}$ ). In rheumatoid arthritis positive correlations were found between serum hyaluronate and acute-phase plasma proteins, while neither rheumatoid factor titre nor the presence of circulating immune complexes were related to the hyaluronate levels. Increased serum hyaluronate could not be explained by impaired renal or liver function or by drug therapy. During treatment with corticosteroids but not with non-steroidal anti-inflammatory drugs the serum hyaluronate concentrations were significantly reduced. The data obtained suggested an increased production of hyaluronate in rheumatoid arthritis, and the increase seems to be related to the activity of the inflammatory process.

Key words: ankylosing spondylitis, acute phase plasma proteins, immune complexes, nonsteroidal anti-inflammatory drugs.

Hyaluronate (hyaluronic acid), a high molecular weight polysaccharide, is widely distributed in connective tissues in which it may have both structural and regulatory functions. ${ }^{12}$ Hyaluronate seems to enter the blood circulation via the lymph vessels ${ }^{3}$ and is then rapidly eliminated by the hepatic route. ${ }^{45}$ The mechanisms regulating the in-vivo synthesis of this polysaccharide are unknown, but in-vitro studies suggest so far that hormonal ${ }^{6}$ as well as inflammatory mediators ${ }^{7-9}$ may stimulate an increased production. A suppressive effect of corticosteroids on hyaluronate synthesis has been demonstrated in fibroblast tissue culture. ${ }^{10} 11$ In clinical situations increased amounts of hyaluronate have long been recognised in pleural fluid of patients with mesothelioma ${ }^{12}$ and in synovial fluid of patients with inflammatory arthritides, where it appears with decreased molecular weight. ${ }^{13}$ The lack of specific and sensitive assays for hyaluronate has until now precluded reliable measurements of

Accepted for publication 29 July 1984.

Correspondence to $\mathrm{Dr}$ Anna Engström-Laurent, Division of Rheumatology, Department of Internal Medicine, University Hospital, S-751 85 Uppsala, Sweden. the low concentrations of circulating hyaluronate. However, the recent development of a radioassay for hyaluronate ${ }^{14}$ has allowed its determination in small tissue samples and in various body fluidsaqueous humour, ${ }^{15}$ amniotic fluid, ${ }^{16}$ and serum. ${ }^{17}$

In this study we have measured the serum levels of hyaluronate in patients with rheumatoid arthritis and pelvospondylitis to test the possibility that inflammatory connective tissue diseases are associated with increased serum levels of hyaluronic acid.

\section{Patients and methods}

Serum samples were collected from 37 patients with rheumatoid arthritis. All patients met the criteria of the American Rheumatism Association for definite or classic disease. ${ }^{18}$ Twenty-nine were female. The mean age was 49 years; the mean duration of the disease seven years. The patients had been treated with various non-steroidal anti-inflammatory drugs, which were withdrawn 3-4 days prior to blood sampling. The blood samples were collected between 7.30 and 8.00 am. 
Serum samples were also collected from 18 patients with ankylosing spondylitis. All patients conformed to the New York criteria ${ }^{19}$ and they were all HLA-B27 positive. Fourteen were male. The mean age was 42 years, and the mean duration of disease 14 years. The patients were treated with non-steroidal anti-inflammatory drugs, but 3-4 days before blood collection therapy was withdrawn. Blood sampling was performed under the above mentioned conditions. None of the patients had signs or symptoms of active disease in the peripheral joints. The control group consisted of healthy blood donors.

Hyaluronate was determined according to the principles previously outlined ${ }^{14}$ and recently adapted for measurement in serum samples. ${ }^{17}$ In short, protein with specific affinity for hyaluronate is prepared from cartilage by affinity chromatography and labelled with ${ }^{125} \mathrm{I}$. The preparation procedure has been described in detail. ${ }^{14} 20$ The radioactive protein is incubated with varying amounts of free hyaluronic acid and a fixed amount bound to a Sepharose gel. The protein is allowed to partition between free and bound polysaccharide. The amount of radioactivity pelleted with the gel is a function of the amount of free hyaluronate in the system. $500 \mu \mathrm{l}$ of the serum sample to be analysed is incubated with the reagents for $20 \mathrm{~h}$ at $4^{\circ} \mathrm{C}$ during slow rotation. The reagents are: (1) $400 \mu \mathrm{l}$ of $1.5 \mathrm{M}$ sodium chloride, $0.025 \mathrm{M}$ phosphate buffer, $\mathrm{pH} 7 \cdot 0$, containing $33 \mathrm{mM}$ ethylenediamine-tetraacetic acid (Merck, Darmstadt, FRG), $3 \mathrm{mg} / 1$ soybean trypsin inhibitor (Worthington, Freehold, NJ), $3 \mathrm{mM}$ phenylmethylsulphonyl fluoride (Sigma, St Louis, MO), $17 \mathrm{mM}$ benzamidine (Sigma), $3 \mathrm{mg} / 1$ Pepstatine A (Sigma) and $0.33 \mathrm{M} \varepsilon$-amino-n-caproic acid (Sigma), $3 \mathrm{mM}$ iodoacetic acid; (2) $0.5 \mu \mathrm{l}$ of hyaluronate-substituted gel ${ }^{14}$ suspended in $400 \mu$ of $0.55 \mathrm{M}$ sodium chloride and $0.05 \mathrm{M}$ sodium borate, $\mathrm{pH} 7 \cdot 0$; (3) $100 \mu \mathrm{l}$ of ${ }^{125}$ I-labelled cartilage protein in $4 \mathrm{M}$ guanidinium chloride ${ }^{14}$ about $20000 \mathrm{cpm}$. After incubation the gel is collected by centrifugation and washed twice. Standard curves for hyaluronate are obtained by the use of sodium hyaluronate (Healon, Pharmacia, Uppsala, Sweden) dissolved in saline containing bovine serum albumin (Sigma).

Circulating immune complexes were determined by Professor Renée Norberg, SBL, Stockholm by the use of three different assays: a conglutininbinding assay, ${ }^{21}$ a platelet-aggregation test, ${ }^{22}$ and a C1q-binding assay. ${ }^{25}$ Rheumatoid factors (RF) were measured both by a particle agglutination technique and the Waaler-Rose method at the Department of Bacteriology, University Hospital, Uppsala. The acute-phase plasma proteins haptoglobin, orosomucoid, and $\alpha_{1}$-antitrypsin were measured by nephe- lometry at the Department of Clinical Chemistry and IgG at the Department of Clinical Immunology University Hospital, Uppsala. The erythrocyte sedimentation rate (ESR) was read after $1 \mathrm{~h}$. Blood samples were also subjected to the following analy-

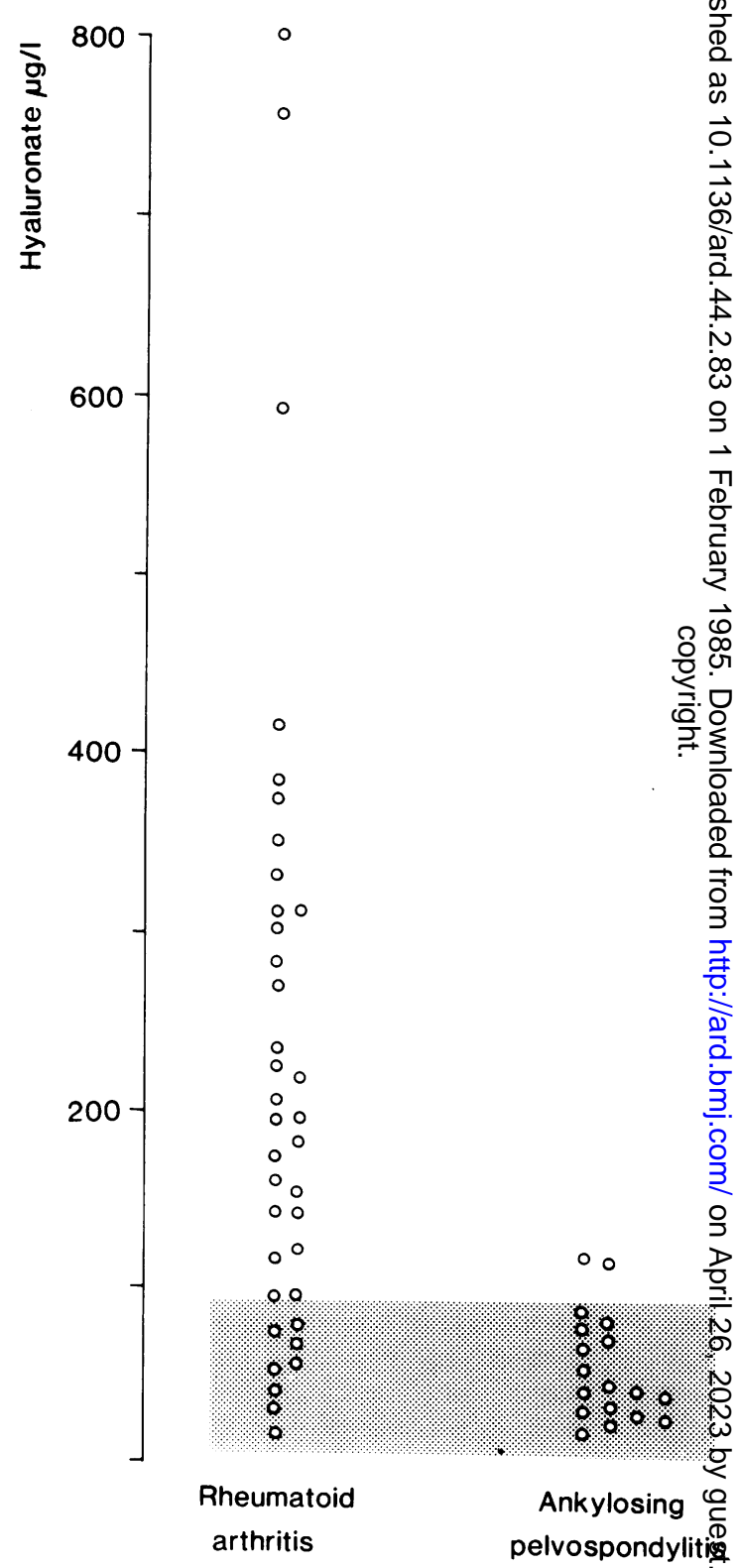

Fig. 1 The individual serum concentrations of hyaluronate in patients with rheumatoid arthritis and ankylosing spondylitis. The shaded area represents the $2 S D$ ranges of serum hyaluronate in age and sex matched healthy controls. 
Table 1 Laboratory features* in patients with rheumatoid arthritis and ankylosing spondylitis

\begin{tabular}{|c|c|c|c|c|c|}
\hline Diagnosis & ESR $\mathrm{mm}$ & Haptoglobin g/l & Orosomucoid g/l & $\alpha_{1}$-Antitrypsin g/l & $\lg G g / l$ \\
\hline Rheumatoid arthritis & $49 \pm 23$ & $3 \cdot 4 \pm 1 \cdot 2$ & $1 \cdot 5 \pm 0 \cdot 5$ & $2.3 \pm 0 \cdot 5$ & $15 \cdot 1 \pm 5 \cdot 4$ \\
\hline Ankylosing spondylitis & $36 \pm 33$ & $3 \cdot 3 \pm 1 \cdot 4$ & $1 \cdot 4 \pm 0 \cdot 6$ & $2 \cdot 3 \pm 0 \cdot 8$ & $13.0 \pm 4.9$ \\
\hline Reference ranges & $1-15$ & $0 \cdot 3-2 \cdot 0$ & $0.4-1.2$ & $1 \cdot 0-2 \cdot 1$ & $8 \cdot 2-19 \cdot 9$ \\
\hline
\end{tabular}

*Mean values $\pm \mathrm{SD}$.

ses: alanine aminotransferase, aspartate aminotransferase, bilirubin, and creatinine by means of a multichannel analyser (Greiner Electronics, Switzerland) with original reagents.

Student's $t$ test and Wilcoxon's signed rank test were applied in the statistical analysis of data.

\section{Results}

SERUM LEVELS OF HYALURONATE IN

RHEUMATOID ARTHRITIS AND ANKYLOSING SPONDYLITIS

The individual hyaluronate concentrations for patients with rheumatoid arthritis and ankylosing spondylitis are shown in Fig 1 . The mean hyaluronate $( \pm S D)$ concentration for each group was as follows: rheumatoid arthritis, $232 \pm 182 \mu \mathrm{g} / \mathrm{l}$ and ankylosing spondylitis $58 \pm 33 \mu \mathrm{g} / \mathrm{l}$. The mean hyaluronate level for patients with rheumatoid arthritis was significantly greater $(p<0.001)$ than that of the

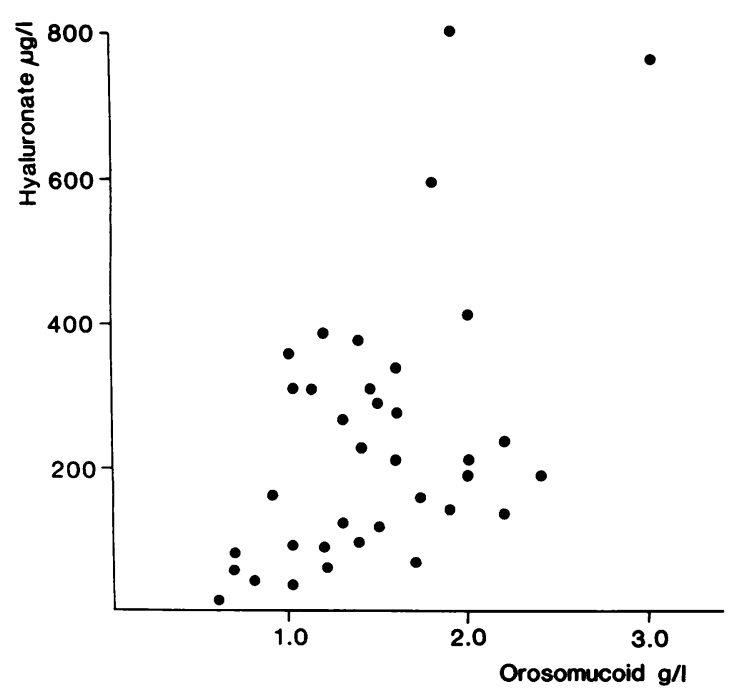

Fig. 2 Relationship between serum levels of hyaluronate and the acute-phase protein orosomucoid, in patients with rheumatoid arthritis and without therapy. age and sex matched control group (mean level $41 \pm 25 \mu \mathrm{g} / \mathrm{l})$ as well as that for patients with ankylosing spondylitis $(\mathrm{p}<0.001)$. No sex and age dependency was noted in the patient groups. None of the patients had laboratory signs of liver or renal disease.

HYALURONATE CONCENTRATIONS AND SEROLOGICAL INFLAMMATORY ACTIVITY The inflammatory activity defined by ESR and certain acute-phase reactants and the serum levels of IgG was similar in the two patient groups (Table 1). In patients with rheumatoid arthritis we found significant correlations of hyaluronate serum levels with orosmucoid $(r=0.5, p<0.01)$ (Fig. 2), haptoglobin $(\mathrm{r}=0.40, \mathrm{p}<0.05)$, and $\alpha_{1}$-antitrypsin $(r=0.61, p<0.001)$ concentrations, and with ESR $(r=0.34, p<0.05)$. The duration of disease was not related to the hyaluronate concentrations.

HYALURONATE CONCENTRATIONS AND IMMUNE COMPLEXES

We found no differences in hyaluronate concentrations of rheumatoid arthritis patients with or without circulating immune complexes measured by different techniques (Table 2). Neither did the RF titre influence the hyaluronate concentrations (data not shown).

Table 2 Serum hyaluronate concentrations* in patients with rheumatoid arthritis in relation to the presence of circulating immune complexes as detected by three different assays

\begin{tabular}{llll}
\hline Assay & & $n$ & Hyaluronate $\mu g / l$ \\
\hline C1q-assay & $\begin{array}{l}\text { positive† } \\
\text { negative }\end{array}$ & 22 & $240 \pm 42$ \\
Platelet-aggregation & $\begin{array}{l}\text { positive } \\
\text { negative }\end{array}$ & 12 & $233 \pm 39$ \\
Assay & 20 & $192 \pm 39$ \\
Conglutinin-binding & positive & 12 & $267 \pm 44$ \\
Assay & negative & 20 & $211 \pm 25$ \\
\hline
\end{tabular}

*Means \pm SEM.

†Positive $=$ immune complexes detectable, negative $=$ immune complexes not detectable 
Table 3 Acute effects of corticosteroids and NSAID on the circulating levels of hyaluronate* in patients with rheumatoid arthritis

\begin{tabular}{|c|c|c|c|c|}
\hline Drug & $n$ & $\begin{array}{l}\text { Hyaluronate } \\
\text { Before } \\
\text { therapy }\end{array}$ & $\begin{array}{l}\text { concentrations } \\
\text { After } 1 \text { week } \\
\text { of therapy }\end{array}$ & $\begin{array}{c}(\mu g / l) \\
p\end{array}$ \\
\hline $\begin{array}{l}\text { Methylprednisolone } \\
\text { NSAID }\end{array}$ & $\begin{array}{l}11 \\
16\end{array}$ & $\begin{array}{l}254 \pm 60 \\
190 \pm 30\end{array}$ & $\begin{array}{l}118 \pm 13 \\
227 \pm 34\end{array}$ & $\begin{array}{l}<0.02 \\
>0.05\end{array}$ \\
\hline
\end{tabular}

${ }^{*}$ Means \pm SEM.

\section{HYALURONATE CONCENTRATIONS DURING} DRUG TREATMENT

The hyaluronate levels were significantly reduced in rheumatoid arthritis patients after one week on therapy with methylprednisolone (15-25 mg daily), but no significant acute change was noted in patients receiving non-steroidal anti-inflammatory drugs (NSAID); (indomethacin, naproxen, diclofenac) alone $(n=5)$ or in combination with penicillamine $(n=6)$ or chloroquine $(n=5)$ (Table 3$)$. Four of the above patients treated with methylprednisolone? were serially studied for up to nine months. Asis illustrated in Fig. 3, there was a conspicuous decrease of serum hyaluronate after the first week oț treatment with methylprednisolone at daily dosages $15-25 \mathrm{mg}$. After that time azothioprine $(100 \mathrm{mg}$ pef day), cyclophosphamide (50-100 mg/day), or chlor oquine ( $250 \mathrm{mg}$ per day) was added to the treatment? of three patients, while one patient remained onP steroids only. The steroid dosage was gradually reduced, and at nine months the daily methylprednio solone intake was $5-7.5 \mathrm{mg}$. At that time we् observed that the hyaluronate concentrations started to increase again.

\section{Discussion}

This study has demonstrated increased circulatingT levels of hyaluronate in rheumatoid arthritis patients?

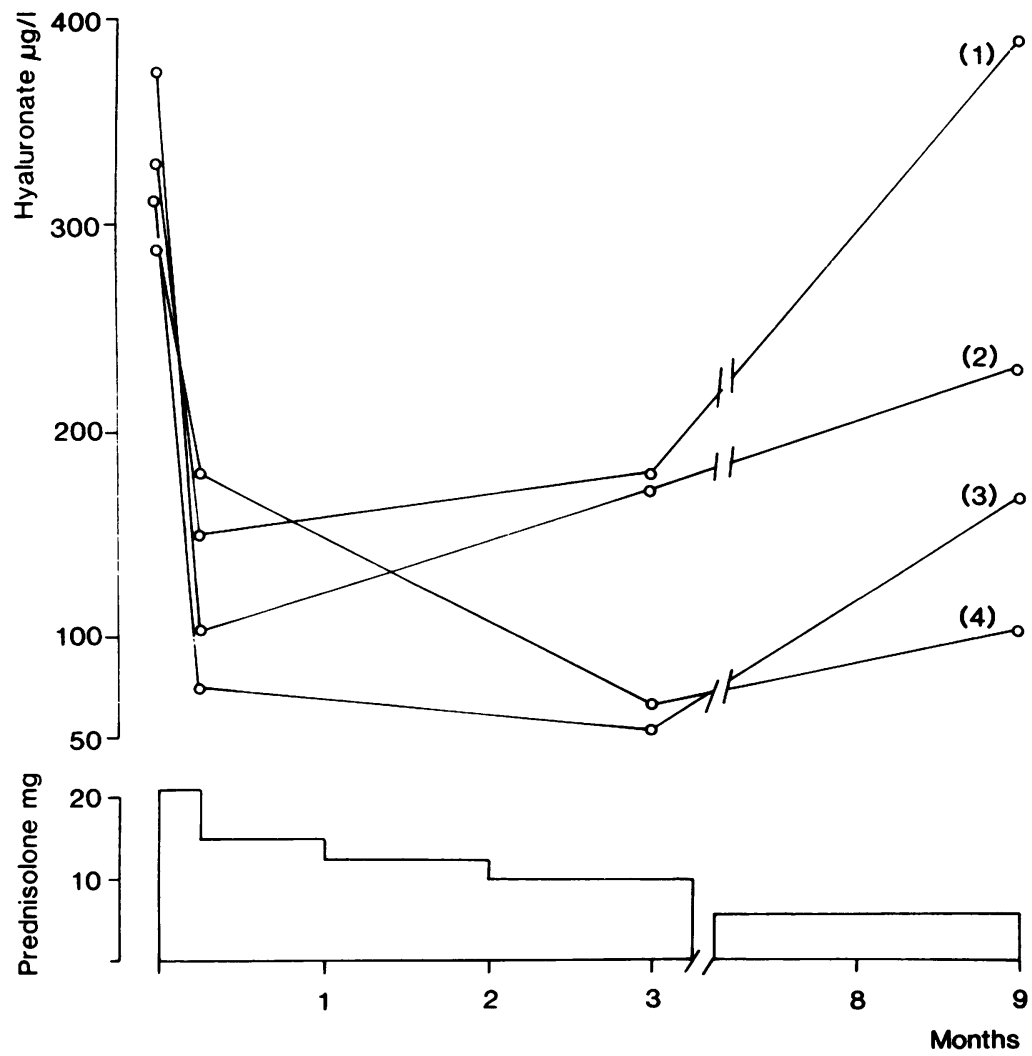

Fig. 3 Serial studies of serum hyaluronate in four patients with $\overrightarrow{0}$ rheumatoid arthritis. At the start of the study they were without drug therapy. During the first week the were treated with methylprednisolone, on average $2 \bar{Q}$ mg per day, as the only drug. The $\mathrm{O}$ corticosteroids were then gradually reduced. The average methylprednisolone dosage is $\rightarrow$ illustrated. Patient 1 remained on steroids only, while after the first week of steroid treatment cyclophosphamide was added for $N$ patient 2, chloroquine for patient and azathioprine for patient 4. 
compared with age and sex matched healthy controls. The observed high serum concentrations of hyaluronic acid should depend on either an accelerated production or a reduced elimination rate. The half-life in circulation of ${ }^{3} \mathrm{H}$-acetyl-labelled hyaluronic acid is short, ranging between 2.5 and $5.5 \mathrm{~min}$ both in experimental animals ${ }^{5}$ and healthy volunteers. ${ }^{24}$ It has further been demonstrated in vitro that the uptake and degradation of hyaluronate occur in the endothelial cells of the liver sinusoids. ${ }^{25}$ Observations of very high serum levels of hyaluronate in cirrhotic patients, related to the degree of impaired liver function, emphasise the central role of the liver in hyaluronate metabolism (EngströmLaurent A, Lööf L, Nyberg A, to be published). However, our patients with rheumatoid arthritis had no laboratory signs of liver affection. Furthermore, recent studies (Fraser J R E, Engström-Laurent A, Nyberg A, to be published) have shown that the plasma clearance of injected labelled hyaluronate in patients with rheumatoid arthritis is normal. Therefore the increased hyaluronate values found in the present study are presumably not a consequence of impaired elimination or degradation of this polysacharide but rather a consequence of stimulated synthesis or outflow from the connective tissue.

The factors stimulating an increased production of hyaluronate in rheumatoid arthritis have not been identified, but evidently the serum concentrations of rheumatoid factor or immune complexes do not influence the circulating hyaluronate levels. The significant positive relationship between acutephase plasma proteins and hyaluronate concentrations in rheumatoid arthritis suggests that an increased synthesis of hyaluronate might be linked to the intensity of the inflammatory process. However, hyaluronate itself does not behave as a non-specific acute phase reactant, since patients with ankylosing spondylitis and with similar degree of laboratory evidence of inflammatory activity (see Table 1) had normal serum hyaluronate concentrations. Since our patients with pelvospondylitis had no signs of active peripheral arthropathy, it is reasonable to attribute to the inflamed synovial tissue a critical role for the increased blood concentrations of hyaluronate in rheumatoid arthritis. An increased synovial production of hyaluronate is conceivable in patients with large volumes of synovial fluid. Furthermore experimental studies suggest that circulating hyaluronate could arise from the joints. Thus injection of labelled hyaluronate into the joint cavity of experimental animals demonstrates that already after 2-3 hours considerable amounts of radioactivity have left the joint cavity and passed to the lymph vessels and the blood. ${ }^{26}$ However, further studies applying more sensitive assessments of synovitis status are needed to elucidate the role of the inflamed joint behind elevated serum levels of hyaluronate. Whether or not increased physical activity and more active joint movements could enhance hyaluronate outflow from the normal or inflamed joint is under investigation. It is not unlikely that enzymatic and free radical degradation of hyaluronate ${ }^{27}$ in inflamed joints could result in different molecular sizes of circulating hyaluronate in health and for example, rheumatoid arthritis. However, available techniques do not allow analysis of the molecular state of hyaluronic acid in serum.

Prostaglandin E (PGE) has been observed as a mediator of inflammation, and exogenous PGE is a potent stimulator of hyaluronate synthesis in isolated synovial cells. ${ }^{7}$ The stimulated hyaluronate production observed in vitro during incubation of synovial cells with rubella or measles viruses or interferon has also been considered as a consequence of enhanced PGE production. ${ }^{28}{ }^{29}$ Inhibitors of prostaglandin synthesis such as steroidal and nonsteroidal anti-inflammatory drugs also inhibit the enhanced hyaluronate synthesis in the above experimental systems. ${ }^{28}$ We found that administration of methylprednisolone at a daily dosage of $20 \mathrm{mg}$ to patients with rheumatoid arthritis reduced their circulating hyaluronate values considerably. These observations are consistent with the in-vitro results and could reflect an inhibition of prostaglandins. However, the lack of effect of indomethacin and similar non-steroidal anti-inflammatory drugs on the serum levels of hyaluronate in rheumatoid arthritis might suggest that prostaglandins are not the main stimulators of hyaluronate synthesis in this disease.

This study has shown that the serum hyaluronate concentration is high in rheumatoid arthritis but not in ankylosing spondylitis, although the biochemical evidence of disease activity was equally raised in both patient groups. The practical clinical value of hyaluronate determinations in rheumatoid arthritis is at present uncertain. Prospective studies are in progress with the object of assessing the relation of hyaluronate to the extent of articular and extraarticular manifestations in rheumatic diseases and the long-term influence on hyaluronate serum levels of different treatments. Whether the in-vitro observations on the effects of hyaluronate on lymphocytes, ${ }^{30} 31$ monocytes/macrophages, ${ }^{32-34}$ and neutrophils ${ }^{35} 36$ are relevant to in-vivo situation has not yet been settled. However, the possibility of a modulatory role of hyaluronic acid in inflammation is another fascinating aspect of this polysaccharide which also merits further investigation.

This work was supported by grants from the Swedish Medical Research Council, Gustaf V 80 Year Fund, the Medical Faculty of Uppsala, and the Swedish Association against Rheumatism. 
References

1 Laurent T C. Structure of hyaluronic acid. In: Balazs E A, ed. Chemistry and molecular biology of the intercullular matrix. London and New York: Academic Press, 1970: 703-32.

2 Mason R M. Recent advances in the biochemistry of hyaluronic acid in cartilage. Progr Clin Biol Res 1981; 54: 87-112.

3 Laurent U B G, Laurent T C. On the origin of hyaluronate in blood. Biochem Int 1981; 2: 195-9.

4 Fraser J R E, Appelgren L-E, Laurent T C. Tissue uptake of circulating hyaluronic acid. A whole body autoradiographic study. Cell Tissue Res 1983; 233: 285-93.

5 Fraser J R E, Laurent T C, Pertoft $\mathrm{H}$, et al. Plasma clearance, tissue distribution and metabolism of hyaluronic acid injected intravenously in the rabbit. Biochem $J$ 1981; 200: 415-24.

6 Wong G L, Kent G N, Ku K Y, et al. The interaction of parathormone and calcium on the hormone-regulated synthesis of hyaluronic acid and citrate decarboxylation in isolated bone cells. Endocrinology 1978; 103: 2274-82.

7 Castor C W. Connective tissue activation. VII. Evidence supporting a role for prostaglandins and cyclic nucleotides. $J$ Lab Clin Med 1975; 85: 392-404.

8 Yaron M, Castor C W. Leukocyte-connective tissue cell interaction I. Stimulation of hyaluronate synthesis by live and dead leukocytes. Arthritis Rheum 1969; 12: 365-74.

9 Yaron M, Yaron I, Smetana O, et al. Hyaluronic acid produced by human synovial fibroblasts: effect of polyinosinicpolycytidylic acid (Poly I:C) and interferon. Arthritis Rheum 1976; 19: 1315-20.

10 Castor C W. Adrenocorticoid suppression of mucopolysaccharide formation in human connective tissue cultures. J Lab Clin Med 1962; 60: 788-98.

11 Saarni H, Hopsu-Havu V K. The decrease of hyaluronate synthesis by anti-inflammatory steroids in vitro. $\mathrm{Br} \mathrm{J} \mathrm{Dermatol}$ 1978; 98: 445-9.

12 Suzuki Y. Pathology of human malignant mesothelioma. Semin Oncol 1980; 8: 268-82.

13 Sundblad L. Glycosaminoglycans and glycoproteins in synovial fluid. In: Balazs E A, Jenaloz R W, eds. The amino sugars. New York: Academic Press, 1965: 11A: 229-50.

14 Laurent U B G, Tengblad A. Determination of hyaluronic acid in biological samples by a specific radioassay technique. Anal Biochem 1980; 109: 386-94

15 Laurent U B G. Hyaluronate in aqueous humour. Exp Eye Res 1981; 33: 147-55.

16 Dahl L, Hopwood J, Laurent U B G, et al. The concentration of hyaluronate in amniotic fluid. Biochem Med in press.

17 Engström-Laurent, A, Laurent U B G, Lilja K, et al. Concentration of sodium hyaluronate in serum. Submitted for publication.

18 Ropes M W, Bennet G A, Cobb S, et al. Diagnostic criteria for rheumatoid arthritis. Ann Rheum Dis 1959; 18: 49-53.

19 Bennet P H, Burch T A. New York symposium on population studies in the rheumatic diseases: new diagnostic criteria. Bull Rheum Dis 1967; 17: 453-8.
20 Tengblad A. Affinity chromatography on immobolized hyalur onate and its application to the isolation of hyaluronate binding protein from cartilage. Biochem Biophys Acta 1979; 578: 281-9?.

21 Casali P, Bossus A, Carpentier N A, et al. Solid-phase enzym immunoassay or radioimmunoassay for the detection of ims mune complexes based on their recognition by conglutiniro conglutinin-binding test. Clin Exp Immunol 1977; 29: 342-54등

22 Myllylä G, Vaheri A, Penttinen K. Detection and characteriza $\overline{\bar{c}}$. tion of immune complexes by the platelet aggregation test. II Circulating complexes. Clin Exp Immunol 1971; 8: 399-408

23 Hay F C, Nineham L J, Roitt I M. Routine assay for the detection of immune complexes of known immunoglobulin class using solid phase C1q. Clin Exp Immunol 1976; 24: 396-400 $\overrightarrow{0}$

24 Fraser J R E, Laurent T C, Engström-Laurent A, Laurent U B G. Elimination of hyaluronic acid from the blood stream ir the human. Clin Exp Pharmacol Physiol 1984; 11: 17-25. Oू

25 Eriksson S, Fraser J R E, Laurent T C, et al. Endothelial celloి are the site of uptake and degradation of hyaluronic acid in the liver. Exp Cell Res 1983; 144: 223-8.

26 Antonas K N, Fraser J R E, Muirden K D. Distribution of biologically labelled radioactive hyaluronic acid injected into joints. Ann Rheum Dis 1973; 32: 103-11.

$27 \mathrm{McCord}$ J M. Free radicals and inflammation. Protection o응 synovial fluid by superoxide dismutase. Science 1974; 185? 529-31.

28 Yaron M, Yaron I, Wiletzki C, et al. Interrelationship betweerm stimulation of prostaglandin $\mathrm{E}$ and hyaluronate production by poly (I) poly (C) and interferon in synovial fibroblast culture Arthritis Rheum 1978; 21: 694-8.

29 Yaron M, Yaron I, Smetana O, et al. Stimulation of prostaglan=din $\mathrm{E}$ and hyaluronic acid production by rubella and meastes viruses in human synovial fibroblast cultures. Arthritis Rhe्gme 1981; 24: 573 .

30 Balazs E A, Darzynkiewicz Z. The effect of hyaluronic acid fibroblasts, mononuclear phagocytes and lymphocytes. $\operatorname{In} \leqslant$ Kulonen E, Pikkarainen J, eds. Biology of the fibroblast London: Academic Press, 1973: 237-52.

31 Darzynkiewicz Z, Balazs E A. Effect of connective tissu民口 intercullular matrix on lymphocyte stimulation. Suppression oR lymphocyte stimulation by hyaluronic acid. Exp Cell Res 1971 66: $115-8$.

32 Love S H, Shannon B T, Myrvik Q N, et al. Characterization of macrophage agglutinating factor as a hyaluronic acid-protein complex. J Reticuloendothel Soc 1979; 25: 269-82.

33 Shannon B T, Love S H. Additional evidence for the role of hyaluronic acid in the macrophage disappearance reaction Immunol Commun 1980; 9: 735-46.

34 Forrester J V, Balazs E A. Inhibition of phagocytosis by high molecular weight hyaluronate. Immunology 1980; 40: 435-46.

35 Håkansson L, Hällgren R, Venge P. Effect of hyaluronic acioß on phagocytosis of opsonized latex particles. Scand J Immunoß 1980; 11: 649-53.

36 Håkansson $L$, Hällgren $R$, Venge $P$. Regulation of granulocyte function by hyaluronic acid. J Clin Invest 1980; 66: 298-305 